\title{
Editorial
}

\section{The Politics of Aid in the Age of Globalization}

\author{
WENDY HARCOURT
}

With the impact of globalization, development co-operation is increasingly under question, even seen as marginalized in some world debates. Global economic crises, escalating conflicts and the new geo-politics of the post-Cold War era overshadow the North-South dialogue. The articles in this issue of Development challenge this trend head-on. They show that the crisis of globalization has forced a rethinking on the old style of development co-operation. The politics of justifying aid today demands an exposure of past faulty political and economic allegiances. 'Business as usual', riddled by self-interest, cultural insensitivity, corruption and fatal blows to communities and environments, has to change. But the answer is not just for donor countries to pull out, for the North-South-East dialogue to close and the ground cleared for markets and globalization to carry on full-swing. These authors from a variety of positions show that there is too much at stake for the majority of the world - the economically poor - for development just to close shop.

The articles aim to persuade the reader that the show must go on. The first group of articles are those by men and women from within the development establishment who, as leading policy-makers and academics, have tried to steer a just set of practices for development. The articles, culled from the North-South Roundtable meeting held in Tidewater in 1998, indicate that there are many within the development establishment who are willing to take a long, hard look at the development framework in order to move out from under the shadow cast by globalization. These are a generation of women and men who have devoted their professional and personal lives to the goals of achieving human centred development. As insiders, they are trying to uncover the institutional problems of donor countries while asking for greater participation of recipients of aid and major changes in how development is conducted. 
Even with the threat of globalization and the endemic decline of aid, they illustrate how, with demonstrable public support, they could put development co-operation back on a surer footing. The articles are written with a sense of hope that new paths can be forged, learning from the mistakes of the past and working with a much larger array of actors and a more sophisticated understanding of how to conduct democracy, governance and participation in the age of globalization.

Other voices in the journal echo these sentiments but from a different set of players. These writers are based outside traditional multilateral institutions or research institutes and belong to the growing number of civil society groups that are becoming more and more central to a North-South dialogue negotiating new forms of partnership. These are the actors who are forming new political spaces and alliances as people's groups from different regions work together. They are acutely aware of the historical power plays among nations that have led to the increasing number of economically poor despite stated best intentions. They are also willing to face the challenge of globalization. As members of civil society they claim to represent closely the needs of the poor communities that development claims to help and they are willing to experiment in how to create participatory institutions that include more people in the partnership. They embrace cultural diversity, age, gender and ethnic specificities, listening to the different strong responses of communities to globalization. While still acknowledging the validity of the development establishment reforms, in many ways they are striking out along other paths.

For both sets of players there is a strong will to make the big players accountable, to bring in the small players through the right forms of governance and appropriate set of institutions. Values such as democracy and justice are put centre stage, as are the mechanisms that would allow for diversity and creativity to flourish. The difficulty is how to open up institutions that were set up in a very different sort of world and how to institutionalize very fluid and spontaneous arrangements so that the two groups can respond together.

It seems that in this journal issue we have a possible bridge - the commitment to participation of the economically poor in deciding their own lives and arrangements. The issue here is how the different voices can come together in order to build the political support for the economically poor to change their lives in a world where the market appears to call the shots. The challenge to find systems that are built on values other than those promoted by the market is a challenge that the development world with its long term commitment to closing gaps between the rich and poor should be able to meet. Perhaps the combined wisdom of the two generations could come together to provide the vision and practical where-with-all to set a new political agenda for the North-South-East dialogue - one that goes beyond the boundaries of traditional development co-operation and embraces the new spaces being opened up by civil society. As two of the giants of development - Amartya Sen and James Wolfensohn - recently stated in a joint submission to the International Herald Tribune (5 May 1999),

The end of the Cold War has been accompanied by a growing recognition of the importance of political, social and economic participation, by widespread demands for human rights and gender equity, and by an emerging globalized economy. This offers an unprecedented opportunity to make development work. . . . Reaching that goal must involve wide participation ... only then will development be broadly based and broadly owned.

We hope that this journal is a contribution to our collective move along that path. 